\title{
Evaluating human resources practices in resort hotels during recession periods
}

\author{
Hany Essam El-Din Mohamed \\ Faculty of Tourism and Hotel Management \\ Helwan University
}

\author{
Ahmed Mohamed Atef \\ Higher institute for specific studies \\ Giza
}

\begin{abstract}
This study aimed to assess the human resources practices adopted by a number of five-star hotels in Marsa Alam and Dahab during times of recession. Employee satisfaction is a significant challenge to human resource management (HRM) especially during valley periods. As a result of the revolution of the 25th of January 2011, employee satisfaction has decreased significantly due to hotels' low occupancy rates that resulted in decreased salaries. To achieve the aim of the research, two research tools were used embracing the questionnaire and the interview. Fifty six questionnaires were completed by employees in a number of five-star resort hotels in Marsa Alam and Dahab, five properties in each to identify human resource practices experienced by them. On the other hand, ten managers were interviewed in the same hotels to identify their perspectives regarding human resources practices towards employees during recession periods. Research findings revealed the importance of developing employee loyalty and training programs to maintain high performance levels during recession. Doing this could lead to customer satisfaction, repeat business, and improved profitability.
\end{abstract}

KEYWORDS: human resources practices, recession, resort hotels

\section{Introduction}

Hospitality organizations need continually to confirm the satisfaction of their employees (Berry, 1997). Organizations' effectiveness lurks behind satisfying their employees (Robbins and Judge, 2007). Satisfied employees are believed to be an effective labor force and become a vital benefit that proves to be useful for the organization's efficiency (Masri, 2009).

Previous research proposed that an organization's employees can be a source for constant competitive advantage and can guarantee the success of their organizations (Prahalad, 1983; Pfeffer, 1994). Given the importance of people in organizations, most strategic human resource departments consider the management of the competencies and capabilities of these human assets the primary goal. Moreover, hospitality is considered as an unstable industry due to its dependency on human factors. (Kuria et al., 2012). Furthermore, Bharwani and Butt (2012) added that human resources are one of the main parts of the product performing the difficult role of enhancing the organizational image. As in other industries, hospitality highly depends on humans having direct contact with their customers. Van de Voorde and Beijer (2004) stated that HR management was an essential factor in staff performance, fairness and justice, training and development, and employee stratification.

Terrorism and economic slowdown can be particularly harmful to the tourism industry and previous studies have shown that terrorism and economic crisis negatively affect the number of international tourist arrivals in countries affected by the crisis or cause a decrease when the generating markets are affected by the crisis. Terrorism and economic downturn bring about changes in consumer behavior, increased unemployment and loss of income (Smeral, 2009). However, the revolution of January which started in the 25 of January of 2011 has had a profound impact on the economies of Egypt. Tourism demand has been most affected by adverse economic conditions.

The research included studies that described different occurrences of terror (Aziz, 1995; Pizam and Mansfeld, 1996), classification of violent activities relevant to the industry (Pizam, 1999; Faulkner and Russell, 2000), the political and economic benefit associated with cessation of terror activities (Anson, 1999; Butler and Baum, 1999).

Sönmez et al. (1994) referred to a tourism crisis as a situation that can threaten the normal operation of a tourism-related business or damage tourism destination's reputation, Meanwhile, O'Halloran (2000) illustrated that hospitality operations can use the word of CRISIS as an acronym to illustrate key factors for dealing with a crisis situation:

Cash flow and communication: Financial management and adequate recourses may save a business.

Responsiveness: quick reflective response to all stakeholders is vital to a crisis.

Involvement: be involved in the management of a crisis

Speed: is vital for management decision making

Insurance: more than adequate insurance is necessary to fend off a litigious world

Safety: put safety first for guests, employees, management and the community

Wang et al., (2009) illustrated that there are six main characteristics of an organizational crisis, as follows:

(1) High ambiguity with unknown causes and effects.

(2) A low probability of its occurrence.

(3) An unusual and unfamiliar event.

(4) The requirement for a rapid response.

(5) A significant threat to the survival of the organization and stakeholders.

(6) The need for a quick decision that potentially has positive or negative effects. 
Employees' dissatisfaction will influence their commitment to work negatively and lead them to turnover from the organization physically and/or mentally (Pathak, 2012). Tracey and Hinkin (2008) stated that employees' turnover rates are affected by employees' dissatisfaction within the job environment and lessen their job contribution. Therefore, with the help of human resources, an organization can boost their business. Yet, employees' various needs make it difficult to keep their employment. Thus, it is important to focus on understanding employees' needs to achieve their satisfaction (Masri, 2009). Boella (2000) referred to voluntary termination as a situation that takes place when an employee decides to terminate the relationship with the employer for personal or professional reasons. On the other hand, Gomez-Mejia et al. (2001) added that the employer begins involuntary termination. Involuntary termination takes place when management decides to end its relationship with an employee because of:

- Economic necessity

- Inappropriateness between the employee and the organization.

Valley (off-peak) period is that time in which consumers refuse to use the service. During valley periods, airlines, hotels, tour operators, and other travel companies offer low prices to encourage and attract more consumers to use the service (Pride and Ferrell, 1997; Feltner, 2003). Rutherford (2002) referred to the valley period as the period which occurs when supply transcends demand on the marketplace. Zaki (2006). On the other hand, valley periods are periods of the year when both demand for a destination and prices decline. Furthermore, Kumar et al. (2010) explained human resource practices in valley periods as follows:

1. Laying off employees to decrease labor force

2. Using unpaid vacation to reduce labor force

3. Lessening the number of workdays weekly

4. Freezing pay rates

5. Replacing highly paid employees with new low paid ones

6. Escalating reliance on outsourcing

Terrorism and economic crises are the terms which are often, used to determine unwanted events that have a substantial effect. In spite of the vibrations, a crisis is known as a low probability. High impact situations are unexpected, unfamiliar, and caused by people, organizational structures, economics, technology or natural disasters (Reilly, 1987; Pearson and Clair, 1998).

According to Zaki (2006), there are five stages of crisis. These are:

[1] Pre-crisis (e.g. prior to the event or before knowing its circumstances).

[2] Warning (e.g. signs of that there could be an event or circumstance that may affect the organization vitally).

[3] Crisis point (e.g. the point at which the event begins to lead to an important influence upon the organization).

[4] Recovery (e.g. the point at which the acute stage of the crisis has passed and the organizations are able to concentrate on returning to normal operations).

[5] Post-crisis (e.g. times for evaluating the impact of the crises and for letting the organization follow the right path). In addition, Combos (2010) defined three phases of crisis management as follows: Pre crisis, Crisis and Post-crisis.

Table1: Crisis Management Phases

\begin{tabular}{|c|c|}
\hline Crisis Management phases & Measures applicable \\
\hline Pre-crisis & Preventive measures signal detection, prevention preparation \\
\hline crisis & Crisis management Plan recognition of the triggering event and response \\
\hline Post-crisis & Post-crisis, evaluate actions after operations have returned to normal \\
\hline
\end{tabular}

Source: (Combos, 2010)

\section{Materials}

This study was conducted on five hotels in Marsa Alam and Dahab destinations, five properties in each. Employees' questionnaire and personal interviews with managers were conducted.

The questionnaire form was developed based on the relevant review of literature. The main purpose of this questionnaire is to know and evaluate human resources policies towards employees during recession in resort hotels. The questionnaire includes questions concerning:

- The compulsory rebate of total salary.

- $\quad$ Satisfaction with the policies adopted by the hotel management during recession.

- $\quad$ Ranking the different practices adopted by the management during recession.

- How the employees evaluate some work environmental attributes during valley periods.

The questionnaire was distributed to a sample of employees in the resort hotels in the following functional areas: Front Office, Housekeeping, Food Service and kitchen. A total of 100 questionnaires were distributed (10 forms in each hotel). Only 56 from the answered forms were valid (56\%). This paper shows a comparison between employees who work in Marsa Alam and those in Dahab in terms of "the existence of compulsory rebate of total salary during valley periods", "employees satisfaction with policies of the human resources department during recession", "employees' opinions concerning the corresponding work law" and "work conditions". For this purpose Mann-Whitney U test was used. 
Interviews were carried out with ten managers (five managers from Marsa Alam hotels and five managers from Dahab) to identify their perspectives regarding human resources policies towards the investigated issues. The interview was structured in a way that illustrates the practices of hotel management during the valley periods.

Results and Discussion

\section{Descriptive analysis of Employee's questionnaire}

The employee's questionnaire form consists of six questions to reveal the data of employees who work in resort hotels during recession as follows: the compulsory rebate of total salary, arranging the most human resources practices during valley periods, employees' satisfaction regarding policies practiced by the human resources, employees' opinion concerning work law protection from resort management and identifying the staff satisfaction regarding working attributes, namely salary, medical insurance, motivation, working hours, training, management appraisal of workers and overall satisfaction with management.

Question No.1: Employees' answers regarding the compulsory rebate of total salary during valley periods

Table 2: Employees' answers regarding the compulsory rebate of total salary during valley periods

\begin{tabular}{|l|c|c|c|c|c|c|c|}
\hline $\begin{array}{l}\text { compulsory } \\
\text { rebate }\end{array}$ & freq & $\%$ & Hotel & $\begin{array}{l}\text { Mean Rank } \\
\text { Score }\end{array}$ & $\begin{array}{c}\text { Std. } \\
\text { Deviation }\end{array}$ & $\begin{array}{c}\text { Mann-Whitney } \\
\text { U Test }\end{array}$ & Asymp. Sig. (2-tailed) \\
\hline Yes & 39 & 69.6 & Marsa & 27.48 & .464 & 348.000 & .414 \\
\hline No & 17 & 30.4 & Dahab & 29.76 & & \\
\hline
\end{tabular}

As shown in Table, 2, 69.6\% of all the employees mentioned that there is a compulsory rebate of total salary during valley periods, as against $30.4 \%$ of them illustrating that there is not compulsory rebate of total salary during valley periods. Furthermore, 29 employees 51.8\% mentioned that the compulsory rebate consists of declining 12\% service which constitutes a large part of the salary. This finding agrees with Angel and Cannella (2004) who stated that the wage factor produced the major intent to turnover and job dissatisfaction.

The results show that no significant differences $(\mathrm{P}<0.05)$ between employees' answers in Marsa Alam and Dahab resort hotels regarding the compulsory rebate of total salary. From the employees' viewpoint, they suffer from compulsory rebate of total salary during recession as investigated in both of Marsa Alam and Dahab resort hotels.

Question No.2: Employees' answers regarding their satisfaction with the policies used by the human resources during recession

Table 3: Employee's answers regarding their satisfaction with the policies used by the human resources during recession

\begin{tabular}{|c|c|c|c|c|c|c|c|}
\hline Employees' satisfaction & freq & $\%$ & Hotel & $\begin{array}{c}\text { Mean Rank } \\
\text { Score }\end{array}$ & Std. Deviation & $\begin{array}{c}\text { Mann-Whitney U } \\
\text { Test }\end{array}$ & Asymp. Sig. (2-tailed) \\
\hline Yes & 7 & 12.5 & Marsa & 27.48 & \multirow[t]{2}{*}{.334} & \multirow[t]{2}{*}{356.000} & \multirow[t]{2}{*}{.365} \\
\hline No & 49 & 87.5 & Dahab & 29.76 & & & \\
\hline
\end{tabular}

Table 3 clarifies that $87.5 \%$ of the employees were dissatisfied with human resources practices, while $12.5 \%$ of them were satisfied. This means that hotel managers should try to satisfy employees and let them participate in putting strategies during valley periods in order to achieve their satisfaction as well as to reduce the employees' fear. These findings agree with Haven-Tang and Jones (2012) as well as Kusluvan et al. (2010) who indicated that poor human resources practices, poor management, low wages, bad working environment, and paucity of job opportunities could be the highest causes of turnover.

The results also reflect no significant $(\mathrm{P}<0.05)$ differences between employee's answers in Marsa Alam and Dahab resort hotels regarding their satisfaction with the policies used by the human resources during recession.

Question No.3: Ranking major practices followed by human resources during recession

This question was designed to identify the staff answers to the major practices followed by human resources during recession (e.g. stopping recruitment, moving the employee from one hotel to another within the same hotel chain, halting allowances like $12 \%$ service charge, and laying off workers). (Table 4 )

Table 4: Ranking major practices followed by human resources during recession

\begin{tabular}{|c|c|c|c|c|c|c|c|c|}
\hline \multirow[t]{2}{*}{ Major practices } & \multicolumn{5}{|c|}{ Practices levels } & \multirow[t]{2}{*}{ Total } & \multirow[t]{2}{*}{ Weighted average \% } & \multirow[t]{2}{*}{ Ranking } \\
\hline & 1 & 2 & 3 & 4 & 5 & & & \\
\hline 1- Stopping recruitment. & - & - & - & 8 & 12 & 92 & 92 & 1 \\
\hline $\begin{array}{l}\text { 2- Moving the employee from } \\
\text { one hotel to another within the } \\
\text { same hotel chain. }\end{array}$ & 3 & 13 & 3 & 1 & - & 42 & 42 & 4 \\
\hline $\begin{array}{l}\text { 3- Halting allowances (e.g. } 12 \% \\
\text { service charge). }\end{array}$ & 2 & 2 & 14 & 1 & 1 & 57 & 57 & 3 \\
\hline $\begin{array}{l}\text { 4- Permitting vacations without } \\
\text { salary. }\end{array}$ & 15 & 3 & 2 & - & - & 27 & 27 & 5 \\
\hline 5-Laying off workers. & - & 2 & 1 & 10 & 7 & 82 & 82 & 2 \\
\hline
\end{tabular}


It can be concluded from Table (4) that stopping recruitment was considered as one of the most important major practices of human resources during valley periods with an average of $92 \%$; followed by laid off employees who did not complete a three-month recruitment test period with an average of $82 \%$; thirdly, halting allowances (e.g. 12\% service) with an average of 57\%, fourthly moving the employee from one hotel to another within the same hotel chain (an average of $42 \%$ ) and finally permitting vacations without salary (an average of 27\%). Finally, the findings illustrate that Human resources prefer Stopping recruitment and Laying off of workers who did not complete a three-month recruitment. Therefore, hotel managers should be fully aware of the employees' opinions regarding the policies of human resources during valley periods in order to attain their satisfaction.

The findings of this issue indicate the noticeable importance of good working conditions. As it is known, bad working conditions, low salaries, work stress, and injustice employees trigger will leave their work (Hemdi et al., 2012;; Pathak, 2012). The operations should encourage some employees to agree to take unpaid vacations during low season to reduce the employer's payroll and avoid the need for laying off (Dessler, 2000).

Question No.4: Employees' opinions concerning work law which protects them from resort management during valley periods

Table 5: Employees' opinions concerning work law which protects them from resort management during valley periods.

\begin{tabular}{|l|c|c|c|c|c|c|c|}
\hline Work law protection & freq & $\%$ & Hotel & $\begin{array}{l}\text { Mean Rank } \\
\text { Score }\end{array}$ & $\begin{array}{c}\text { Std. } \\
\text { Deviation }\end{array}$ & $\begin{array}{c}\text { Mann-Whitney U } \\
\text { Test }\end{array}$ & Asymp. Sig. (2-tailed) \\
\cline { 1 - 5 } Yes & 2 & 3.6 & Marsa & 27.69 & .464 & 362.500 & .200 \\
\hline No & 54 & 96.4 & Dahab & 29.50 & & \\
\hline
\end{tabular}

As shown in Table 5, 96.4\% of the employees mentioned that there is no work law that can protect them from resort management during valley periods, while 3.6\% of them explained that there is work law protection. Moreover, 11 employees (19.6\%) stated that if the hotel decides to layoff any one of employees, the hotel will make bad evaluation for him to terminate him easily. After the termination, the hotel does not compensate the employee even if he has worked since twenty years ago at such a hotel. These finding concur with Zaki (2006) who suggested that amending labor laws relating to tourism sector by including guarantee methods to solve the problems of employees during the crises and tourism valley periods, i.e. to protect the rights of temporary and casual employees.

There are no significant differences $(\mathrm{P}<0.05)$ between employees in Marsa Alam resort hotels and those in Dahab (Table 5) in terms of employees' opinions concerning the work law which protects them from resort management during valley periods. According to the viewpoints of both of them, unfortunately the work law does not protect the employees from management practices.

\section{Question 5: Employees' answers regarding work attributes during Valley periods}

The purpose of this question is to identify the staff satisfaction with working attributes during valley periods, to achieve this purpose staff evaluate the following attributes (salary, medical insurance, monetary or moral motivation, working hours, quality and regularity of training, management appraisal and overall satisfaction with management during valley periods) (Table 6).

Table 6 : Employees answers regarding work attributes during valley periods

\begin{tabular}{|c|c|c|c|c|c|c|}
\hline \multirow[t]{2}{*}{ Attributes } & \multicolumn{2}{|c|}{ Good } & \multicolumn{2}{|c|}{ Fair } & \multicolumn{2}{|c|}{ Poor } \\
\hline & Freq & $\%$ & Freq & $\%$ & Freq & $\%$ \\
\hline 1- Salary. & 3 & 5.3 & 9 & 16.1 & 44 & 78.6 \\
\hline 2- Medical Insurance. & 28 & 50 & 16 & 28.6 & 12 & 21.4 \\
\hline 3- Monetary or moral motivation. & 10 & 17.9 & 15 & 26.8 & 31 & 55.3 \\
\hline 4- Working hours. & 3 & 5.4 & 6 & 10.7 & 47 & 83.9 \\
\hline 5- Quality and regularity of training. & 6 & 10.7 & 12 & 21.4 & 38 & 67.9 \\
\hline 6- Management appraisal & 21 & 37.5 & 22 & 39.3 & 13 & 23.2 \\
\hline 7- Overall satisfaction with management during valley periods. & 7 & 12.5 & 8 & 14.3 & 41 & 73.2 \\
\hline
\end{tabular}

Firstly, in terms of employees' satisfaction regarding salary in resorts during valley periods, $78.6 \%$ of the staff stated that their salary was bad. On the other hand, $5.3 \%$ of them mentioned that their salary was good (Table 6). As it is known, salary is one of the incitements, which is central; no other motivational strategy or rather impetus comes nearer to it as to its compelling nature (Rynes et al., 2004). Wages have the overwhelming nature to polarize, maintain and move employees towards achieving superior. Frederick Taylor and his logical administration associate certified that, the most basic factor of motivation of the mechanical laborers to 
accomplish more noteworthy yield is salary (Adeyinka et al., 2007). All associations utilize development, pay, rewards or different sorts of prizes to motivate and push for an abnormal state of exhibitions by their workers (Reena et al., 2009).

Secondly, concerning employees' satisfaction with medical insurance, $50 \%$ of the staff stated that medical insurance was good. While, $21.4 \%$ stated that it was bad. These findings concur with Hayes and Ninemeier (2006) who mentioned that fringe benefits can also be significant, including employer-provided rewards and services other than wages and salaries. Examples include life and health insurance, paid vacation, and employerprovided meals.

Thirdly, regarding the employees' satisfaction with monetary or moral motivation, $55.3 \%$ of them stated that their motivation was bad, meanwhile, $17.9 \%$ illustrated that it was good. This finding concurs with Gomez-Mejia et al. (2007) who indicated that that it is essential that managers have a basic understanding of work motivation because highly motivated employees are more likely to produce a superior-quality product or service than employees who lack motivation.

Fourthly, concerning the working hours $83.9 \%$ of the respondents reported a negative opinion, while, $10.7 \%$ stated that the working hours were fair. On the other hand, 5.4\% of them scored them good. This finding is supported also by AlBattat and Som (2013) who indicated that the main factors affecting employees satisfaction during recession were unfavorable working conditions, stress, long working hours with minimal wages and poor training programs.

Fifthly, with reference to employees' satisfaction with the quality of training, $67.9 \%$ of them stated that the quality and regularity of training were bad. On the other hand, $10.7 \%$ were satisfied with this issue. These findings concur with Walters and Raybould (2007) who stated that a number of HRM practices have been suggested as potential solutions for turnover during recession, such as investment in training, offering organisational support, adopting innovative recruitment selection processes, and offering better career opportunities to increase job satisfaction.

Sixth, regarding employees' satisfaction with management appraisal, 39.3\% of them mentioned that the management appraisal was fair, while, $23.2 \%$ were not satisfied regarding their appraisal.

Seventh, in terms of overall satisfaction with management $73.2 \%$ of them were dissatisfied, $12.5 \%$ were satisfied.

\section{Comparison between employees in Marsa Alam resort hotels and those in Dahab regarding work attributes}

This comparison is used to determine if there is a significant difference between employees in Marsa Alam resort hotels and those in Dahab. Also, a mean rank score is used for this comparison (Table 7).

Table 7: A summary of the Mann-Whitney $U$ test for employees in Marsa Alam and those in Dahab in terms of working attributes

\begin{tabular}{|c|c|c|c|c|c|}
\hline Working attributes & Hotel & $\begin{array}{c}\text { Mean } \\
\text { rank score }\end{array}$ & Std. Deviation & $\begin{array}{c}\text { Mann-Whitney } \\
\text { U test } \\
\end{array}$ & $\begin{array}{c}\text { Asymp. Sig. } \\
\text { (2tailed) }\end{array}$ \\
\hline \multirow[t]{2}{*}{ Salary } & Marsa Alam & 28.02 & \multirow[t]{2}{*}{.55567} & \multirow[t]{2}{*}{372.500} & \multirow[t]{2}{*}{.729} \\
\hline & Dahab & 29.10 & & & \\
\hline \multirow[t]{2}{*}{ Medical insurance } & Marsa Alam & 27.98 & \multirow[t]{2}{*}{.80259} & \multirow[t]{2}{*}{371.500} & \multirow[t]{2}{*}{.774} \\
\hline & Dahab & 29.14 & & & \\
\hline \multirow[t]{2}{*}{ Monetary or moral motivation } & Marsa Alam & 25.77 & \multirow[t]{2}{*}{.77606} & \multirow[t]{2}{*}{303.000} & \multirow[t]{2}{*}{.121} \\
\hline & Dahab & 31.88 & & & \\
\hline \multirow[t]{2}{*}{ Working hours } & Marsa Alam & 27.56 & \multirow[t]{2}{*}{.52964} & \multirow[t]{2}{*}{358.500} & \multirow[t]{2}{*}{.454} \\
\hline & Dahab & 29.66 & & & \\
\hline \multirow[t]{2}{*}{ Quality and regularity of training } & Marsa Alam & 32.24 & \multirow[t]{2}{*}{.68376} & \multirow[t]{2}{*}{271.500} & \multirow[t]{2}{*}{.020} \\
\hline & Dahab & 23.86 & & & \\
\hline \multirow[t]{2}{*}{ Management appraisal } & Marsa Alam & 28.74 & \multirow[t]{2}{*}{.77292} & \multirow[t]{2}{*}{380.000} & \multirow[t]{2}{*}{.895} \\
\hline & Dahab & 28.20 & & & \\
\hline \multirow{2}{*}{$\begin{array}{l}\text { Overall satisfaction with management during } \\
\text { valley periods }\end{array}$} & Marsa Alam & 29.08 & \multirow[t]{2}{*}{.70527} & \multirow[t]{2}{*}{369.500} & \multirow[t]{2}{*}{.702} \\
\hline & Dahab & 27.78 & & & \\
\hline
\end{tabular}

As shown in Table (7), it can be noticed that the Mann-Whitney $U$ test revealed no significant difference between employees in Marsa Alam and those in Dahab resort hotels in terms of working attributes. Both of them suffer from management during valley periods. In that sense, hospitality managers, especially in Marsa Alam and Dahab, should be fully aware of this matter in order to achieve the employee's satisfaction specifically in valley periods and to increase the profitability as well. Managers of hotels should know the reasons behind employees' dissatisfaction in Marsa Alam and Dahab. 
Question No.6:

Employees' recommendations that help management to enhance staff satisfaction during valley periods

1. Adoption of intensive advertising campaigns relying on modern ideas such as advertising Egyptian destinations on famous global sports channels.

2. Not relying mainly on tour operator but rather on other methods of marketing such as social media, attracting Egyptian customers and corporate companies.

3. Dealing with new markets (Southeast Asian or Arab customers) rather than relying on the Russian tourism.

4. Targeting the best market segmentation which is characterized by high spending power to raise the $12 \%$ service charge.

5. Resort hotels management should pay more attention to the regularity of systematic training and motivation.

6. Resort hotels should work to achieve perfect environment for productivity with no fear.

7. Resort management should practice employees lay off as the last policy during valley periods.

\section{Interviews with managers' analysis}

This section presents the findings of personal interviews in the investigated hotels under eight main headings which are: most employees are harmed during valley periods, ranking major practices followed by human resources, exploiting and managing regularity of training, training contribution of the Ministry of Tourism, the existence of crisis fund financed by the resort administration and workers to face any problems during recession, problems facing resort management during recessions to satisfy employees, changing staff profession or job or field of hospitality during valley periods and, finally, managers' recommendations that help resort hotels to improve human resources management during recessions.

\section{1- Most employees are harmed during valley periods}

All managers in the investigated resort hotels except three managers agree that the employees who worked in service are the most harmed ones during valley periods. Furthermore, two managers added that employees of housekeeping are deeply harmed. Again, one manager added that the kitchen staff suffers the most during valley periods. These findings are supported by two of the interviewees who commented that:

The whole hotel was affected by tourism crises. Therefore all workers were so affected especially after the Russian plane crash, and now the majority of the employees who work now were casual labor.

Briefly, it can be concluded from the previous findings that most managers in the investigated resort hotels agree that all employees are equally harmed during valley periods especially those of the food and beverage department.

2- Ranking major practices followed by human resources during valley periods Table 8: Major practices followed by human resources during recession

\begin{tabular}{|c|c|c|c|c|c|c|c|c|}
\hline \multirow[t]{2}{*}{ Major practices } & \multicolumn{5}{|c|}{ Practices levels } & \multirow[t]{2}{*}{ Total } & \multirow{2}{*}{$\begin{array}{c}\text { Weighted } \\
\text { average } \%\end{array}$} & \multirow[t]{2}{*}{ Ranking } \\
\hline & 1 & 2 & 3 & 4 & 5 & & & \\
\hline 1- Stopping designation & 1 & 22 & 12 & 10 & 11 & 176 & 62.8 & 3 \\
\hline $\begin{array}{l}\text { 2- Moving the employee from one hotel to another } \\
\text { within the same hotel chain }\end{array}$ & 24 & 13 & 4 & 7 & 8 & 130 & 46.4 & 4 \\
\hline 3- Halting allowances (e.g. 12\% service) & 1 & 2 & 15 & 21 & 17 & 219 & 78.2 & 1 \\
\hline 4- Permitting vacations without salary & 28 & 10 & 9 & 2 & 7 & 118 & 42.1 & 5 \\
\hline 5- Lay off workers & 2 & 9 & 16 & 16 & 13 & 197 & 70.3 & 2 \\
\hline
\end{tabular}

It can be concluded from Table (8) that halting allowances (e.g. 12\% service, travel allowance, vacation allowance) was considered as one of the most important major practices of human resources with an average of $78.2 \%$. On the other hand, permitting vacations without salary was the least practices of human resources with an average of $42.1 \%$. Briefly, it can be concluded that most managers agree that halting allowances i.e., 12\% service charge and laying off workers who did not complete a three-month recruitment are the main practices followed by human resource department during recession. These findings are supported by two interviewees:

Suitable solution in valley periods is halting or reducing allowances (e.g. 12\% service) because of low rate of occupancy, but this solution, of course, affects the worker's salary. Moreover, when the crisis occurs, the first two procedures we take are to stop recruitment and to lay off anyone who has not completed the 3month recruitment period. 


\section{3- Exploit training during valley periods}

Four managers in the investigated hotels stated that the hotel usually exploits training during valley periods because of the importance of training to improve efficiencies of employees during peak season to do high performance when tourism flourishes again. On the other hand, three hotel managers mentioned that there is a shortage in financing training programs because of recession, but hotels depend on the managers to make training before briefing. Three hotel managers' added that high turnover rates do not permit to make training courses and, so, we wait for tourism to come back and exploit training in raising employees' performance. All managers mentioned that there is no regularity in training and the training is not systematic. These findings are supported by two of the interviewees who clarified that:

Unfortunately, in recession, we do not have the privilege of doing regular training sessions because of high turnover rates and financial incapability.

In summary, it can be noticed from the above findings that there is low attention towards training during recessions and there is no regularity concerning training. The managers should realize that training is the primary way to develop the employees' performance especially in valley seasons to be ready in peak seasons. This will help the hotels to achieve customer satisfaction and service quality to maximize the profits as well.

\section{4- Training contribution of tourism ministry during valley periods}

All managers in the investigated hotels mentioned that there is no training contribution of the Ministry of Tourism nowadays. Furthermore, all managers affirmed that every hotel does training for their staff according to finance efficiencies. These findings are supported by three of the interviewees who stressed on that: Actually there was training from the Ministry of Tourism for hotels from 2004 to 2014 but it was finally stopped in 2014. This affects the quality of the staff as well as service introduced to our guests.

These findings are supported by two of the interviewees who indicated that:

The Ministry of Tourism is supposed to pay more attention to training in times of recession such as the period after the revolution of the $25^{\text {th }}$ of January, but on the contrary, the interest in training has become less from the Ministry of Tourism. The Ministry of Tourism has abandoned hotels in the most dangerous times of the hotels.

It can be noticed from the previous findings that all of the investigated hotels did not benefit from the Ministry of Tourism regarding training nowadays. It can be remarked that every hotel has a training strategy to implement based on its financial capabilities.

\section{5- The existence of crisis fund financed by the resort administration and workers to face any problems during recessions}

Eight managers in the investigated hotels stated that unfortunately the administration is not interested in creating a fund to cope with recession. On the other hand, two managers referred to the existence of a crisis fund to solve the problems of employees during valley periods. These findings are supported by three interviewees who mentioned that:

With the help of our staff, fund is created in a friendly way by the administration to solve the problems of workers such as helping in their marriage expenses or illness.

Thus, it can be concluded that most managers agree that there is no crisis fund to solve the problems of employees during valley periods but some of them establish it in a friendly way.

\section{6-Problems facing resort management during recessions to satisfy employees}

All managers in the investigated hotels reported that there are some problems facing resort management during recessions to satisfy employees such as low salaries and the decline of the $12 \%$ service charge. Furthermore, three managers stated that low tipping is the main problem facing management to meet the staff satisfaction especially resorts which applied the all-inclusive system. Two managers added some problems facing management such as staff shortage which leads to long working shift. These findings are supported by one interviewee who declared that:

Now the income of staff working in resort hotels during recession has decreased to its lowest level because of the declining tipping and 12\% service charge. Moreover, Employee's layoff and turnover are the main problems in the majority of resorts and cause a big shortage in the staff. Therefore, the staff available in the resort work for longer hours to cover shortage. In addition, the employee works in more than one job. For example, a server works at the same time as a barman to compensate for shortage of staff.

Briefly, it can be concluded from the previous findings that most managers in the investigated resort hotels agree that there are some other problems facing resort management during recessions to satisfy employees such as:

1- Low salary and tipping

2- The decline of the $12 \%$ service charge

3- Staff shortage that leads to long working hours 


\section{7- Changing staff profession, job or field of hospitality during valley periods}

The executives were asked to describe how the long duration of recession triggers a change of staff profession, which, in turn, affects negatively on hospitality industry. The following paragraphs present this issue.

All managers stated that high a percentage of employees leave and change their profession. This is for many reasons such as low salaries compared to the standard of living and tourism suffering for a long time with no improvement to find better opportunity with good salary. Three managers added that nowadays many employees get married to foreigners and travel with them to find better jobs abroad. Two managers added that the resort management knows the situation of the employee who tends to change his profession due to his lack of sense of safety. In this case, the employee does not feel safe because of the frequent lay-off of his colleagues. These findings are supported by one interviewee who said that:

In trying to encourage our employees to remain, we told them that the coming period will be better, but unfortunately we are still suffering from recession. We have lost our credibility with our employees and we have lost many of the experienced staff in hospitality.

It can be concluded from the above mentioned interviews and quotes that some managers believe that there is a large leakage of hospitality workers due to the poor conditions of tourism. On the other hand, other managers believe that the hospitality industry will keep their talents when the tourism comes back as usual.

\section{8- Managers' recommendations that help resort hotel for improving human resources management} during recessions

1. The resort hotels should apply and increase the motivate activities of the employees and concentrate on moral recognition programs because these do not need any financial capabilities, like "the ideal employee" and "sports day more than monetary programs".

2. Creation of a crisis team, including employees from each division. The main role of the team is to plan for the solution of the crisis before it happens. That is, this crisis team serves to be proactive rather than being reactive.

3. The Ministry of Tourism should take care of regular training in all divisions of hotels, especially in times of recession.

4. Establishing a crisis fund that deals with the problems of employees during periods of recession, financed by the resort administration.

5. Marketing Egypt abroad strongly in modern ways through international channels such as global sports channels or putting "visit Egypt" on any famous global team's T-shirts.

6. In case the Egyptian destination cannot be marketed well outside Egypt, we will pay attention to domestic tourism via promoting it with fair prices. This will enable management to enhance the salary of employees which could raise the $12 \%$ service charge.

7. Hotels should establish training management and have training coach for their hotels and hotels have to train the employees in a systematic manner to keep the best performance all the time especially in valley periods.

8. Keeping the security and safety of Egypt as it was before the revolution of the $25^{\text {th }}$ of January to keep high percentage of occupancy.

\section{Recommendations}

\section{Recommendations for Egyptian government}

1. Marketing Egypt strongly outside Egypt in modern ways through international channels such as global sports channels or putting (visit Egypt) on any famous global team.

2. Restoring the security and safety of Egypt as it was before the revolution of the $25^{\text {th }}$ of January to retrieve back the high percentage of past occupancy.

3. The Ministry of Tourism should take care of training, especially in times of recession or valley periods.

4. Dealing with new markets (Southeast Asian or Arab customers) rather than relying on the Russian tourism.

\section{Recommendations for Hotel Managers}

1. Should be paid attention to domestic tourism via promoting it with fair price. This will enable management to enhance the salary of employees which could be the reason of raising the $12 \%$ service charge.

2. Designing loyalty programs for employees especially in valley periods such as organizing sports day festivals and rewarding ideal employees by offering them to stay for one week for free with his family in a hotel of the same chain.

3. Hotels have to train the employees in a systematic manner to keep the best performance during valley periods all the time and making cross training for employees who are characterized by high performance outside Egypt in the same hotel chain.

4. Creation of a crisis team, including employees from each division before the crisis takes place and planning for future to be proactive not to be reactive.

5. Establishing a crisis fund that deals with the problems of employees during valley periods financed by the resort administration. 
6. Targeting the best market segmentation that is characterized by high spending power to raise the $12 \%$ service charge.

7. Employees should be lay off as the last policy during valley periods to let them work with no fear and to feel job security.

Based on the above discussion, a model including six main parts is suggested (see the figure).

A suggested practice model for hotels' managers for promoting perfect environment for employees during valley periods to satisfy them

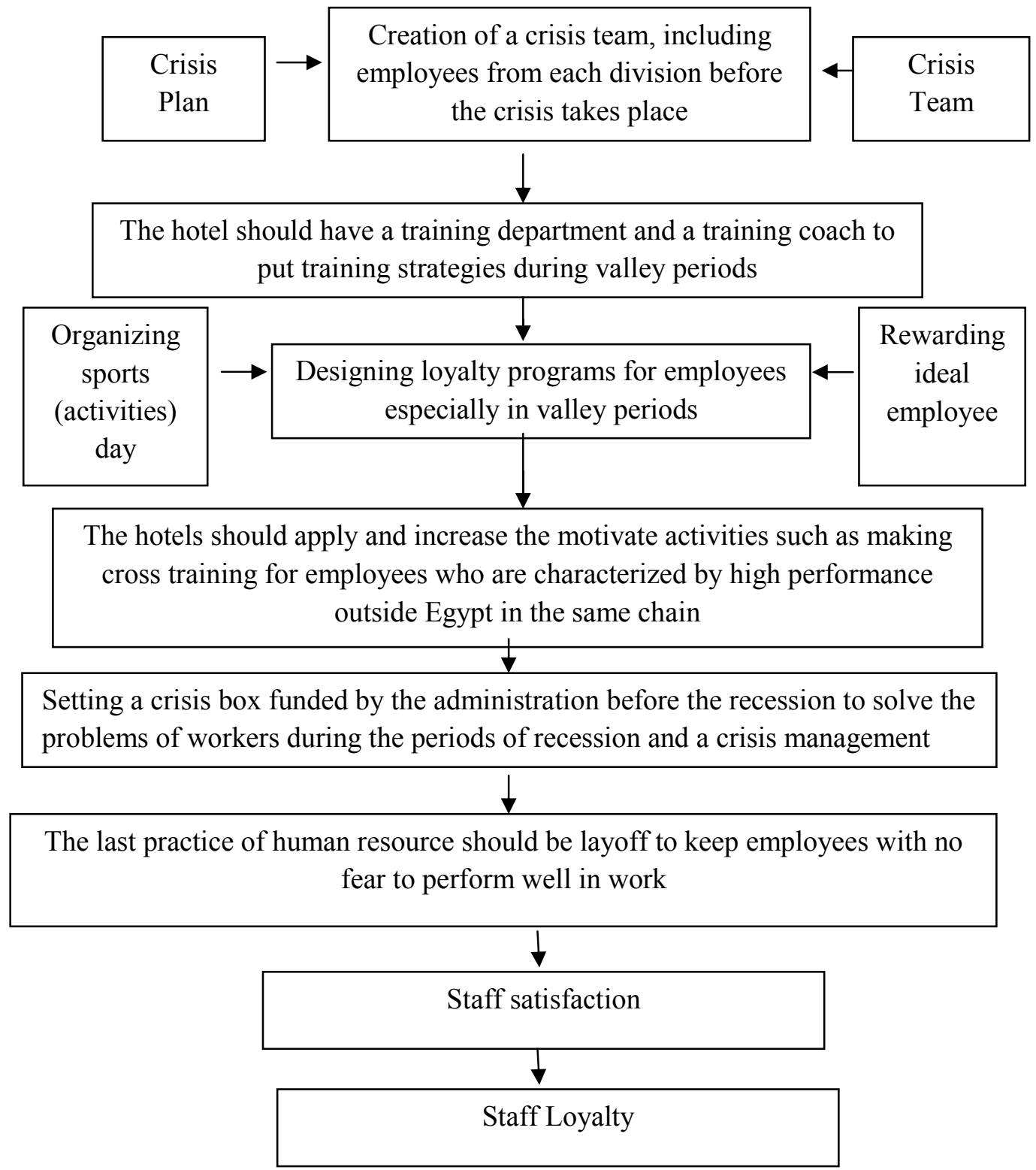

\section{References}

- Adeyinka, M., Allen, R. and Arthur, J.B. (2007). Effects of Human Resource Systems on Manufacturing, Performance, and Turnover. Academy of Management Journal, Vol. 37, pp.67-87.

- AlBattat,A. and Som, A. (2013). Employee Dissatisfaction and Turnover Crises in the Malaysian Hospitality Industry" International Journal of Business and Management. Vol. 8, No. 5, P 64.

- Angel, P. and Cannella, A. (2004). Executive Turnover Revisited From an Efficiency Wage Perspective. The Journal of the Iberoamerican Academy of Management, 2(1), 7-23.

- Anson, C. (1999). Planning for peace: the role of tourism in the aftermath of violence. Journal of Travel Research 38 (August), 57-61. Association, Washington, D.C.

- Aziz, H., (1995). Understanding terrorist attacks on tourists in Egypt. Tourism Management 16, 91-95.

- Berry, L. (1997). Psychology at work. San Francisco: McGraw-Hill Companies Inc. 
- Bharwani, S. and Butt, N. (2012). Challenges for the global hospitality: an HR perspective. Worldwide Hospitality and Tourism Themes, 4(2), 150-162.

- Boella, M.J. (2000), Human Resource Management in the Hospitality Industry, Seventh Edition, Northern Phototypesetting Co. Ltd., Bolton, pp. 166-171.

- Butler, R.W.and Baum,T.,(1999).The tourism potential of the peace dividend. Journal of Travel Research 38(August),24-29.

- Combos, W. T., (2010) Parameters for Crisis communication, in The Handbook of Crisis communication, ed. by W. Timothy Coombs and Sherry J. Holladay (Blackwell Publishing Limited, , pp. 17-53, p. 22.

- Dessler, G. (2000). Human Resource Management, Eighth Edition, Prentice-Hall, Inc., Upper Saddle River, New Jersey, pp.384, 385 .

- Faulkner, B. and Russell, R., (2000). Turbulence, chaos, and complexity in tourism systems: a research direction for the new millennium. In: Faulkner, B., Moscardo, G., Laws, E. (Eds.), Tourism in the 21 st century. Continuum, London.

- Feltner, M. (2003), Low Season, Low Cost: Five Tips for Off Peak Travel, [online]. April, 14, 2016. Available from: http://www.smartertravel.com/advice/advfeatures/advice.

- Gómez-Mejia, L.; Balkin, D.; Cardy, R. and Dimick, D. (2001), "Managing Human Resources", Third Edition Prentice-Hall, Inc., Upper Saddle River, New Jersey, pp. 200-206.

- Gomez-Mejia, L.R.; Balkin, D.B. and Cardy, R.L. (2007), Managing Human Resources Fifth Edition, Upper Saddle River, New Jersey, P.54.

- Haven-Tang, C. and Jones, E. (2012). Local leadership for rural tourism development: A case study of Adventa, Monmouthshire, UK. Tourism Management Perspectives, 4, 28-35. http://dx.doi.org/10.1016/j.tmp.2012.04.006

- Hayes,D.K. and Ninemeier,J.D.(2006),"Foundations of Lodging Management",Upper Saddle River, New Jersey, pp.150-158.

- Hemdi, M.; Omar, M. and Azmi, A. (2012, 12-13 March). The effect of organizational justice and organizational trust on hotel employees turnover intentions. Paper presented at the 3rd International conference on business and economic research (3rd ICBER 2012), Golden flower hotel, Bandung, Indonesia.

- Kumar, B.; Mohsin, A. and Israeli, A. (2010), Hospitality crisis management practices: The case of Indian luxury hotels, International Journal of Hospitality Management, 29 June 2010, P.2

- Kuria, S.; Alice, O. and Wanderi, P. (2012). Assessment of causes of Labour Turnover in Three and five Star-Rated Hotel in Kenya. International Journal of Bussiness and Social Science, 3(15), 311-317

- Kusluvan, S.; Kusluvan, Z.; Ilhan, I., and Buyruk, L. (2010). The Human Dimension A Review of Human Resources Management Issues in the Tourism and Hospitality Industry. Cornell Hospitality Quarterly, 51(2), 171-214. http://dx.doi.org/10.1177/1938965510362871

- Masri, M. (2009). Job satisfaction and turnover intention among the skilled personnel in TRIplc BERHAD. (Master), University Utara Malaysia.

- O'Halloran, R.M. (2000), Crisis Management for Lodging and Hospitality Operation.

- Pathak, D. (2012). Role of perceived organizational support on stress-satisfaction relationship: An empirical study. Asian Journal of Management Research, 3(1), 153-177.

- Pearson, N. and Clair, J. A.(1998). Reframing crisis management. Academy of Management Review,23,pp.59-76.

- Pfeffer, J. (1994) Competitive Advantage through People. Boston Mass.: Harvard Business School Press.

- Pizam, A., (1999). A comparative approach to classifying acts of crime and violence at tourism destinations. Journal of Travel Research 38 (August), 5-12.

- Pizam, A. and Mansfeld, Y. (Eds.), 1996. Tourism, Crime and International Security Issues. Wiley, UK.

- Prahalad, C.K. (1983) 'Developing Strategic Capability: An Agenda for Top Management', Human Resource Management, 22: 237-54.

- Pride, W.M. and Ferrell,O.C.(1997), Marketing Concepts and Strategies, Houghton Mifflin Company,New York, pp.277,278.

- Reena A. and Ahmed, M.S. (2009). The Impact of Rewards and Recognition Programs on Employees Motivation and Satisfaction: An Empirical Study. International Review of Business Reseach Papers, Vol.5, No.4, pp.270-279.

- Reilly, A. H. (1987). Are organizations ready for crisis? A managerial scorecard. Columbia Journal of World Business, 22(1), 79-88.

- Robbins, S. and Judge, T. (2007). Organizational Behaviour (12th ed.). New Jersey: Pearson Education, Inc.

- Rutherford, D.G. (2002). Hotel Management and Operations, Third Edition, John Wiley and Sons, Inc., New York, P.333.

- Rynes, S.L., Gerhart, B.S. and Minette, k.A. (2004). The Importance of Pay in Employee Motivation: Discrepancies between What People say

- Smeral, E. (2009). The impact of the financial and economic crisis on European tourism, Journal of Travel Research, 48 (1), pp.3-13.

- Sönmez, S.F., Backman, S.J. and Allen, L.R., (1994). Managing Tourism Crises: A Guide- book. Department of Parks, Recreation, and Tourism Management, Clemson University, Clemson, SC

- Tracey, B. and Hinkin, T. (2008). Contextual factors and cost profiles associated with employee turnover. Cornell Hospitality Quarterly, 49(1), 12-27. http://dx.doi.org/10.1177/0010880407310191

- Van De voorde, K., and Beijer, S. (2014). The role of employee HR attributions in the relationship between highperformance work systems and employee outcomes. Human Resource Management Journal, 25(1), 62-78.

- Walters, G. and Raybould, M. (2007). "Burnout and perceived organisational support among front-line hospitality employees", Journal of Hospitality and Tourism Management, Vol. 14 No. 2, pp. 144-156.

- Wang, J., Hutchins, H. M., and Garavan, T. N. (2009). Exploring the Strategic Role of Human Resource Development in Organizational Crisis Management. Human Resource Development Review, 8(1), 22-53.

- Zaki, M.M. (2006). Managing Manpower in Hotels During Valley Periods”, Unpublished Master in Hotel Management, Faculty of Tourism and Hotel Management, Helwan University, pp.35,174 


\section{المخلص العربي}

يقوم قسم الموارد البشرية (Human Resources Department)، بذل قصاري جهده للارتقاء بالعاملين وتوفير الجو الملائم لتحقيق مزيد من الإنتاج. و يظهر دور قسم الموارد البشرية بشدة خلال فترات الكساد (valley periods) فيكون دوره فى شدة الصعوبة حيث تكون نسبة الإشغال ضعيفة وفي نفس الوقت مطلوب منه الحفاظ على العمالة المتميزة. وأثنار البحث إلي أن تأثز العاملين فى فنادق مرسى علم ودهب بالأحداث السلبية التى مرت بها البلاد منذ ثورة 25 يناير 2011 حتى الأن مرورا بأحداث وقوع الطائرة الروسية فى عام 2015 كان ناثرا كبيرا ومتتوعا كما أن تصرف الفنادق مع العمالة كان منتابها بشدة حتى مع اختلاف المناطق الواقع بها الفنادق، كما ذكر البحث العديد من ممارسات الموارد البشرية خلال فترات الكساد منل تخفيض الأجور و تخفيض نسبة 12 \% خدمة المبيعات و نقل الموظف من فندق إلى أخر فى نفس السلسله و فتح الإجازات بدون مرتب واخيرا تسريح العمالة. ونت تعريف فترة الكساد بأنها تلك الفترة التى لا يطلب المستهلك فيها الخدمة .ومن خصائص فترة الكساد أن تقدم شركات الطيران و منظمى الرحلات السياحية وشركات السفر الأخرى والفنادق أسعارا أقل لتشجيع وجذب المزيد من المستهكين لاستخدام هذه الخدمات ، وذلك لما تشهده مصر من تتابع للأحداث السياسية والأمنية منذ ثورة 25 يناير حتى الان، كما تطورت الأزمة وفترة الكساد فى مصر لدرجة اضطرار بعض الدول الأجنبية وخاصة الدول الأوروبية إلى حظر السفر إلى مصر ، فانخفضت إثغالات الفنادق وتم إلغاء الحجوزات، مما أدى إلى التوقف التام لبعض الأنشطة السياحية، فانعكس ذلك على العمالة المنتظمة وغير المنتظمه بوجه عام. اما بالنسبة لاستمارات الاستقصاء الخاصة بالعاملين فقد نم توزيعها على عينة من العاملين فى الأقسام المختلفة فى فنادق الخمس نجوم فى مقاصد مرسي علم ودهب وقد نم توزيع 100 استمارة كان من بينها 56 استمارة فقط صالحة للتحليل، وكان الهدف الرئيسى من الاستقصاء هو تقييم ممارسات الموارد البشرية خلال فنرات الكساد فى المنتجعات. وأيضا تم استخدام Mann-Whitney U test للمقارنة بين رضاء العاملين بفنادق مرسي علم وفنادق دهب لمعرفة مدي الرضا بين الفريقين.كما اشتملت الدراسة على مقابلات شخصية مع 10 من المدراء فى مرسي علم ودهب ، وكان الهدف الرئيسى من هذه المقابلات هو التعرف على سياسة الموارد البشرية تجاه العاملين خلال فترات الكساد ،ارتكازا على المراجع التى نم استعراضها ونتائج البحث الميدانى، نم التوصل الى مجموعة من التوصيات موجهة الى وزارة السياحة ومدراء الفنادق لتحقيق ارضاء العاملين من نوفير بيئة جيدة للعاملين خلال فترات الكساد وتحقيق تدريب ممنهج مستمر لضمان الوصول الى أعلي مستوي من الاداء و تحفيز العاملين المعنوي المستمر لضمان استمرار العاملين وتحملهم تتضامنا مع

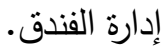

